\title{
The effects of physical-chemical water parameters on the Nymphaeion alliance development in northwestern Serbia
}

\author{
Dejana Džigurski*, Branka Ljevnaić-Mašić, Ljiljana Nikolić \\ Faculty of Agriculture, University of Novi Sad, Trg. D. Obradovića 8, Novi Sad, Serbia
}

\begin{abstract}
Nymphaeion alliance vegetation is dominant floating-leaved vegetation in the Danube-Tisza-Danube hydrosystem in northwestern Serbia and comprises Nymphaeetum albae, Nymphaeetum albo-luteae, Nymphoidetum peltatae and Trapetum natantis associations. Comparative analysis of physical-chemical water parameters on localities where these - in most parts of Europe endangered and vulnerable stands - develop showed that most phytocenoses are associated with specific habitat conditions. Of the analyzed water properties, the factors that cause Nymphaeion alliance phytocenoses differentiation are primarily $\mathrm{pH}$, alkalinity and COD- $\mathrm{MnO}_{4}$. Formation of the Nymphaeetum albae stands is significantly associated with the highest values of $\mathrm{pH}, \mathrm{COD}-\mathrm{MnO}_{4}$ and alkalinity, and the lowest nitrate, nitrite, dissolved and the total phosphorus content values, in comparison to the other studied associations. Nymphoidetum peltatae stands develop in waters characterized by the lowest $\mathrm{pH}$ and $\mathrm{COD}-\mathrm{MnO}_{4}$, low alkalinity, and the highest nitrate and nitrite values in relation to the other analyzed phytocenoses. Trapetum natantis stands, on the other hand, prefer the warmer sections of the canal network, neutral pH, and the highest values of $\mathrm{BOD}_{5}$, dissolved and total phosphorus. Habitat conditions in which Nymphaeetum albo-luteae stands develop are of the widest range in comparison to other investigated phytocenoses.
\end{abstract}

Keywords: Nymphaeion; water properties; Nymphaeetum albae; Nymphaeetum albo-luteae; Nymphoidetum peltatae; Trapetum natantis; Serbia

\section{Introduction}

Floating-leaved plants are a common component of channels, rivers, lakes, ponds and other water basins. Floatingleaved phytocenoses of Nymphaeion Oberd. 1956 alliance play an important role in the shallow aquatic ecosystems [1]. Nymphaeion alliance (order Potametalia W. Koch 1926, class Potametea Tx. et Prsg. 1942, according to Soó [2]) vegetation is the dominant aquatic vegetation in the Hydrosystem Danube-Tisza-Danube (Hs DTD) in the northwestern Serbia. In the aforementioned sections, this alliance is represented by stands of the following associations: Nymphaeetum albae Vollmar 1947, Nymphaeetum albo-luteae Nowinski 1928, Nymphoidetum peltatae (Allorge 1922) Oberd. et Müller 1960 and Trapetum natantis Müller et Görs 1960.

Nymphaea alba, Nuphar lutea and Nymphoides peltata have least concern status on the "Red list of threatened species for Europe" [3], while N. alba and N. lutea have strictly protected national conservation status in Serbia [4]. Nymphoidetum peltatae stands in aquatic vegetation of Vojvodina are in the withdrawal phase [5]. Trapa natans,

\footnotetext{
* Corresponding author. Email: dejana@polj.uns.ac.rs
}

Handling Editor: Aleksandra Samecka-Cymerman the edificator of Trapetum natantis association, is threatened in much of Europe and is subject of conservation efforts aimed at preserving and restoring its population (IUCNLC). T. natans is located on the red lists of many European countries [3], and is included under "Appendix I" of the "Convention on the conservation of European wildlife and natural habitats" (Bern Convention) and IPA list (IPA criterion A, threatened species).

Factors affecting the development and distribution of Nymphaeion alliance phytocenoses were a subject of numerous studies, whereby physical-chemical water parameters [6-10], substrate composition $[6,8,10]$, hydromorphological characteristics [7,11-19], water level fluctuations [18], presence of dams and weirs that disrupt the natural aquatic ecosystem regimen [13], waterflow velocity [20], etc. were investigated. According to Džigurski et al. [21,22], hydromorphological conditions in the studied hydromelioration facility (2-8 m canal depth, variable flow rate and navigation intensity, presence of more than 20 weirs, regulated water level changes, canal age 50-200 years) affect the development of macrophytes differently. Dawson and Szoszkiewicz [23] indicate that Nymphaeion alliance vegetation is typically found in habitats characterized by slow water flow. Findings of several extant studies suggest that, in the key phases of the Nymphaea alba lifecycle, dynamic changes and significant 
increases in the water level adversely affect the development of this species [24,25]. Optimum development of ass. Nymphoidetum peltatae stands is noted in slow-flowing waters $[11,26]$, whereas, although Nuphar luteum favors more stagnant waters, it can tolerate smaller fluctuations in water flow and level [11]. On the other hand, Trapetum natantis is particularly tolerant of rapid water flow and fluctuations in water level $[11,27]$.

The aim of this paper is to present floristic composition, distribution and physical-chemical water parameters of Trapetum natantis, Nimphaeetum albo-luteae, Nimphaeetum albae and Nimphoidetum peltatae stands in northwestern Serbia, which are valuable in the aquatic ecosystem biodiversity conservation efforts. The findings of this study, i.e., the defined optimal levels of the physical-chemical water parameters of these phytocenoses contribute to the implementation of the "European water framework directive" (WFD), which requires monitoring of the ecological status of surface waters [28-31].

\section{Material and methods}

Vojvodina, as the lowest part of the Pannonian Plain, due to the inflow of water masses formed in the Alps, Carpathians and Dinarides, is the largest hydro-confluence in Europe. Owing to this dense network of watercourses, regulation of their unfavorable water regimens was necessary, which was achieved via the construction of the Hs DTD canal network [32]. Hs DTD is a central part of the Rhine-Main-Danube navigational route and one of the largest hydrosystems in Europe (Fig. 1).

Hs DTD is located in the Province of Vojvodina, in northern Serbia $\left(44^{\circ} 39^{\prime} 15.04^{\prime \prime}\right.$ and $46^{\circ} 10^{\prime} 11.32^{\prime \prime}$ north latitude to the $18^{\circ} 50^{\prime} 15.00^{\prime \prime}$ and $21^{\circ} 33^{\prime} 27.82^{\prime \prime}$ east longitude). Bačka part of the Hs DTD comprises a network of nine canals, between the Danube River (in the west and south) and Tisza (in the east), $421 \mathrm{~km}$ in length. In terms of elevation, the network is partitioned into eight pools. In this context, a pool consists of one or more canals delimited by weirs, boat transits and pumping stations, with controlled water regimen. In the region, Hs DTD serves multiple purposes, providing drainage, irrigation, and navigation, and is used for fishing and recreation, as well as industrial and municipal wastewater acceptance.

Long-term studies of aquatic vegetation of Hs DTD in Bačka (Vojvodina Province, Serbia) were conducted in the vegetative period between 2004 and 2007, by applying the Braun-Blanquet method [33]. Plant species were determined according to Josifović [34], Tutin et al. [35,36] and Jávorka and Csapody [37]. All the relevés recorded in the investigated phytocoenoses were aggregated in one synoptic phytosociological table that shows the presence, abundance and coverage degree (from " + " to " 5 "). Only the stands that covered at least the minimum area recommended for these types of vegetation were recorded $\left(>10 \mathrm{~m}^{2}\right)$.

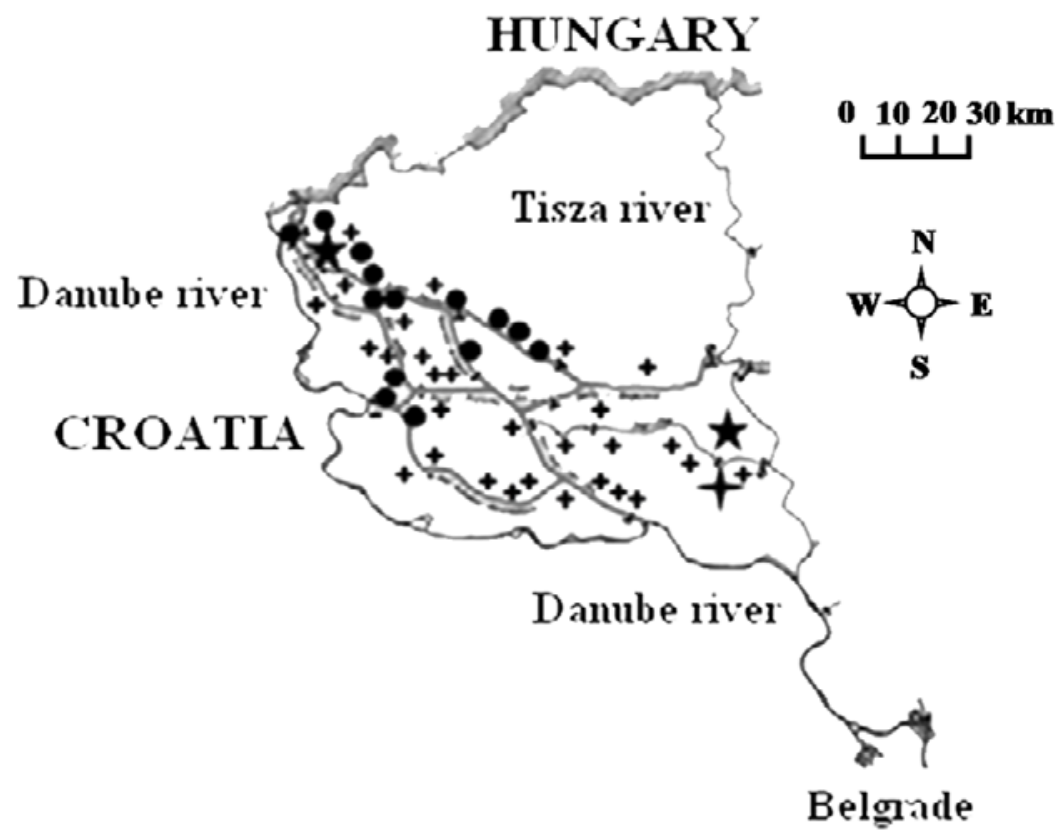

Legend:

canal
$+\quad$ ass. Nymphaeetum albae
- ass. Nymphaeetum albo-luteae
$\star \quad$ ass. Nymphoidetum peltatae
$+\quad$ ass. Trapetum natantis

Fig. 1 Distribution of studied phytocoenoses of Nymphaeion alliance on Hs DTD in Bačka. 
In the study period, the water samples were collected three times a year, during the vegetative period (May-August), $30 \mathrm{~cm}$ from water surface, on the canal sections where existence of Nymphaeion alliance phytocenoses were previously ascertained (Fig. 1). Water samples were taken at locations minimum $400 \mathrm{~m}$ apart. Basic physical and chemical water properties were determined according to standard methods [38]. The following parameters were monitored: temperature, $\mathrm{pH}$ value (with $\mathrm{pH}$-meter), alkalinity, chemical (COD- $\mathrm{MnO}_{4}$ ) and biological $\left(\mathrm{BOD}_{5}\right)$ oxygen demand, and nutrient content $\left(\mathrm{NH}_{4}^{+}, \mathrm{NO}_{3}^{-}, \mathrm{NO}_{2}^{-}, \mathrm{PO}_{4}^{3-}\right.$ and total phosphorus).

The water chemical analysis data pertaining to the aforementioned parameters was processed using STATISTICA 7.0 software [39]. The statistical significance of the differences among the studied phytocenoses, in terms of the analyzed water parameters, was established by applying ANOVA and Fisher LSD-test.

\section{Results}

\section{Species composition of the studied plant associations}

Floating-leaved vegetation Nymphaeion of Hs DTD is represented by stands of associations Nymphaeetum albae, Nymphaeetum albo-luteae, Nymphoidetum peltatae and Trapetum natantis.

Ass. Nymphaeetum albae stands develop at water depths of $0.5-2 \mathrm{~m}$, on the section that is a natural depression and is used as a fishpond (Fig. 1). This section is characterized by a wide waterbed, slow water flow and water level fluctuations of significantly lower intensity compared to the other canal network sections. The studied stands consist of 12 plant species (Tab. 1) - a floristic poverty characteristic of this phytocenosis, on average comprising 2-15 taxa [40]. In addition to floating-leaved species Nymphaea alba, this distinctive collection also includes submerged species Ceratophyllum demersum and Myriophyllum spicatum; thus, this association is significantly bilayer. In the ecological series in the study site, these stands build on the stands of Ceratophylletum demersi (Soó 27) Hild. 1956 and ass. Nymphoidetum peltatae, and towards the shore, emerged stands of Scirpo-Phragmitetum W. Koch 1926 and ass. Typhetum angustifoliae Pign. 1953.

At a significant number of sites within the canal network, ass. Nymphaeetum albo-luteae forms a narrow fringe towards emerged vegetation, only occasionally forming broad bands that extend to the middle of the canal. These stands achieve optimum development in water depths of 1-2.5 m. The floristic composition consists of 18 hydrophytes, whereby the distinctive collection, in addition to the characteristic association species, comprises C. demersum, M. spicatum, Vallisneria spiralis and Salvinia natans (Tab. 1). Ass. Nymphaeetum albo-luteae stands exhibit a typical bilayer structure. In the ecological series, towards deeper water, abundant populations of Myriophyllum spicatum and stands of Ceratophylletum demersi, Ceratophyllo demersi-Vallisnerietum spiralis Lazić 2006, Potametum nodosi Soó (1928) 1960, Segal 1964 and Trapetum natantis are found, and towards the shore, associations Hydrocharidetum morsus-ranae van Langendonck 1935, Salvinia-Spirodeletum polyrrhizae

Slavnić 1956, Scirpo-Phragmitetum, Typhetum angustifoliae and Typhetum latifoliae G. Lang 1973.

Ass. Nymphoidetum peltatae was established on only two, mutually distant sites, at water depths of 0.5-2.5 m. The analyzed stands comprise 15 macrophyte species (Tab. 1). In addition to the edificator, whose abundance and wide coverage provides a unique character to these stands, species of the characteristic group comprising T. natans, Hydrocharis morsus-ranae, C. demersum, V. spiralis, Lemna minor, Spirodela polyrrhiza and S. natans contribute to the heterogeneous structure of these stands. Low values of abundance and coverage of the submerged plants in these stands attest to the significant influence of ass. Nymphoidetum peltatae stands on the reduced growth of submersed macrophytes [41]. At study sites, towards the middle of the canal, ass. Nymphoidetum peltatae stands build on the stands of ass. Ceratophylletum demersi and ass. Nymphaeetum albae, or Sagittaria sagittifolia L. and Potamogeton perfoliatus L. populations. Towards the shore, they are in contact with the stands of ass. Scirpo-Phragmitetum and ass. Typhetum angustifoliae.

Tab. 1 Synoptic table of the Nymphaeion alliance in Hs DTD in Bačka.

\begin{tabular}{lcccc} 
Phytocoenoses & NA & NL & NP & TN \\
Number of relevés & 15 & 32 & 20 & 44 \\
Number of species & 12 & 18 & 15 & 20 \\
\hline
\end{tabular}

\section{Nymphaeion \\ Nymphaea alba L. \\ Nuphar lutea (L.) Sm. \\ Nymphoides peltata Hill. \\ Trapa natans $\mathrm{L}$. \\ Hydrocharis morsus-ranae $\mathrm{L}$. \\ Polygonum amphibium $\mathrm{L}$.}

\section{Potametalia and Potametea}

Myriophyllum spicatum L.

Ceratophyllum demersum $\mathrm{L}$.

Potamogeton perfoliatus $\mathrm{L}$.

Najas marina L.

Vallisneria spiralis $\mathrm{L}$.

Elodea canadensis Rich

Potamogeton crispus L.

Potamogeton pectinatus L.

\section{Others}

Lemna minor L.

Spirodela polyrrhiza (L). Schleid.

Utricularia vulgaris L.

Salvinia natans (L.) Allioni

Lemna trisulca L.

Sagittaria sagittifolia L.

Lemna gibba L.

$\begin{array}{cccc}\mathrm{V}^{3-5} & \mathrm{III}^{1-3} & \mathrm{II}^{+} & \mathrm{I}^{+} \\ & \mathrm{V}^{2-5} & \mathrm{III}^{+-1} & \mathrm{I}^{+} \\ \mathrm{I}^{1} & \mathrm{I}^{+} & \mathrm{V}^{2-5} & \\ \mathrm{I}^{+} & \mathrm{III}^{+-1} & \mathrm{IV}^{+} & \mathrm{V}^{3-5} \\ \mathrm{I}^{+} & \mathrm{III}^{+-1} & \mathrm{IV}^{+-2} & \mathrm{IV}^{+-2} \\ \mathrm{I}^{+} & & & \mathrm{I}^{+}\end{array}$

$\begin{array}{cccc}\mathrm{IV}^{+-2} & \mathrm{IV}^{+-1} & \mathrm{III}^{+-2} & \mathrm{IV}^{+-1} \\ \mathrm{IV}^{+-3} & \mathrm{~V}^{+-3} & \mathrm{~V}^{+-2} & \mathrm{IV}^{+-2} \\ \mathrm{I}^{+} & \mathrm{I}^{+} & \mathrm{II}^{+} & \mathrm{I}^{+-1} \\ \mathrm{I}^{+} & \mathrm{I}^{+} & & \mathrm{I}^{+} \\ & \mathrm{IV}^{+-1} & \mathrm{IV}^{+-1} & \mathrm{II}^{+-1} \\ & \mathrm{I}^{+} & & \mathrm{I}^{+} \\ & \mathrm{I}^{1} & & \mathrm{I}^{+} \\ & & \mathrm{I}^{+} & \mathrm{II}^{+-1}\end{array}$

NA - Nymphaeetum albae; NL - Nymphaeetum albo-luteae; NP Nymphoidetum peltatae; TN - Trapetum natantis. 
Ass. Trapetum natantis is the dominant floating-leaved vegetation in the Hs DTD canal network (Fig. 1) [21]. These stands achieve optimal development in the central, deeper parts of the canal (about $3 \mathrm{~m}$ ), characterized by frequent water fluctuations, as well as in the calm and shallower sections (about $0.5 \mathrm{~m}$ ). They have developed in the form of narrow or wider bands, while covering the entire canal width in some places. The floristic composition consists of 20 species (Tab. 1). In addition to the edificator, the characteristic group includes free-floating $H$. morsus ranae and S. polyrrhiza, and submerged C. demersum and M. spicatum. In deeper waters, in the absence of competition from other floating plants, these stands independently form a wide belt. At lower depths, they form a belt of floating vegetation, together with the stands of communities Nymphaeetum alboluteae, Hydrocharidetum morsus-ranae, Salvinio-Spirodeletum polyrrhizae and Lemno-Spirodeletum. Apart from the floating community stands, in the ecological series, stands of ass. Trapetum natantis build on the submerged stands of associations Ceratophylletum demersi, Ceratophyllo demersiVallisnerietum spiralis and Myriophyllo-Potametum Soó 1934 and the emerged stands of associations Scirpo-Phragmitetum, Typhetum angustifoliae and Typhetum latifoliae.

\section{Physical-chemical water parameters of the analyzed phytocenoses habitat}

The physical-chemical parameter water analysis revealed that $\mathrm{pH}$, alkalinity and $\mathrm{COD}-\mathrm{MnO}_{4}$ are the key factors that cause the phytocenoses differentiation in Nymphaeetum albae, Nymphaeetum albo-luteae, Nymphoidetum peltatae and Trapetum natantis (Fig. 2, Tab. 2, Tab. 3, Fig. 3).

The water temperature analysis revealed that the existing differences are not statistically significant. Mean values ranged from $23.86^{\circ} \mathrm{C}$ on the localities where the stands of ass. Nymphaeetum albo-luteae are formed, through $24.35^{\circ} \mathrm{C}$ in the stands of ass. Nymphoidetum peltatae and $24.5^{\circ} \mathrm{C}$ in the stands of ass. Nymphaeetum albae, to $24.65^{\circ} \mathrm{C}$ in the stands ass. Trapetum natantis (Fig. 2). However, in the ass. Trapetum natantis stand habitats, the extreme temperature of $29^{\circ} \mathrm{C}$ was noted.

The $\mathrm{pH}$ value proved to be a very important factor that caused the phytocenoses differentiation within the Nymphaeion alliance (Tab. 2, Fig. 3). The highest average value (8.172) was noted at sites where stands of ass. Nymphaeetum albae develop, while in all other phytocenoses, it was around 7.6 (Fig. 2). Very broad ecological valence with respect to $\mathrm{pH}$ was observed at the habitats of the stands Nymphaeetum albo-luteae $(\min =7.1, \max =8)$. Statistically highly significant differences between the water $\mathrm{pH}$ values in the habitat of ass. Nymphaeetum albae and ass. Nymphoidetum peltatae ( $P=0.0023$ ) were noted, between those measured in the habitat of ass. Nymphaeetum albae and ass. Trapetum natantis $(P=0.001)$, and between ass. Nymphaeetum albae and ass. Nymphaeetum albo-luteae $(P=0.002)$, Tab. 3 .

Alkalinity significantly differentiated the analyzed associations (Tab. 2, Fig. 3). The highest mean value was measured for the sites populated by the stands of ass. Nymphaeetum albae (5.310), which are also the most tolerant to alkalinity variations $(\min =2.745, \max =6.893)$. These are followed by the bicarbonate content of water in which the stands of ass.
Trapetum natantis (3.507) and ass. Nymphoidetum peltatae (3.114) develop, and finally by the values associated with water dominated by stands of ass. Nymphaeetum albo-luteae (2.844), Fig. 2. Statistically highly significant differences were observed between the habitat alkalinity values of the ass. Nymphaeetum albae and Nymphaeetum albo-luteae stands $(P=0.001)$, and between ass. Nymphaeetum albae and ass. Nymphoidetum peltatae $(P=0.009)$, as well as statistically significant differences between water alkalinity in habitats ass. Nymphaeetum albae and ass. Trapetum natantis $(P=0.013)$, Tab. 3 .

The highest mean chemical oxygen demand value COD$\mathrm{MnO}_{4}(11.7 \mathrm{mg} / \mathrm{l})$ and its greatest variation was noted in stands of Nymphaeetum albae (Fig. 2). In the water where stands of ass. Nymphaeetum albo-luteae develop, the mean value of 7.927 was obtained, whereas for ass. Trapetum natantis and ass. Nymphoidetum peltatae habitats, the mean $\mathrm{COD}-\mathrm{MnO}_{4}$ values of 7.272 and 6.927 were noted, respectively. Statistically highly significant differences in terms of COD- $\mathrm{MnO}_{4}$ were found between localities populated by ass. Nymphaeetum albae and ass. Trapetum natantis stands $(P=0.001)$, as well as between the stands of Nymphaeetum albae and Nymphaeetum albo-luteae $(P=0.003)$, and between the Nymphaeetum albae and Nymphoidetum peltatae $(P=0.001)$, Tab. 2, Tab. 3 .

The obtained mean values of $\mathrm{BOD}_{5}$ - slightly above $2 \mathrm{mg}$ $\mathrm{O}_{2} / 1$ in water where the stands of ass. Nymphaeetum albae (2.1775) and ass. Nymphaeetum albo-luteae (2.488) develop - indicate moderate water pollution. On the other hand, higher mean $\mathrm{BOD}_{5}$ values obtained for water populated by ass. Trapetum natantis stands (3.808), with the extremes exceeding $7 \mathrm{mg} / \mathrm{l}$, are indicative of polluted water. At the border between a relatively clean and moderately polluted waters are the sites where ass. Nymphoidetum peltatae stands develop (mean value 1.70). Overall, the results indicate a "good ecological status" (BOD 5 below $6 \mathrm{mg} / \mathrm{l}$ ) in the category of artificial water bodies, for the majority of sites where the analyzed stands develop, with the exception of a few sites at which stands of ass. Trapetum natantis are found (Fig. 2).

The differences in the ammonium ion content of the investigated stands were not statistically significant. The lowest values were noted at localities populated by ass. Nymphaeetum albo-luteae stands (mean value 0.245 ), while the highest were obtained for those characterized by presence of ass. Nymphaeetum albae stands (mean value 0.437 ; Fig. 2). Of particular significance is the ammonium ion content on some localities populated by stands of ass. Trapetum natantis, reaching $\max =0.62$, and thus indicating that the quality of water is poor (Fig. 2).

The water nitrate content analysis revealed that development of ass. Nymphoidetum peltatae stands favors water richer in these compounds (mean value 1.217), compared to the other stands (Fig. 2). Stands of Trapetum natantis (mean value 0.874 ), Nymphaeetum albo-luteae (mean value 0.827 ) and Nymphaeetum albae (mean value 0.68 ) were also characterized by relatively high nitrate content. No statistically significant differences were noted in the water nitrate content where the analyzed stands develop (Tab. 2).

In the studied aquatic ecosystem, nitrite content had no significant effect on the differentiation of Nymphaeion 
Temperature ( ${ }^{\circ} \mathrm{C}$ )
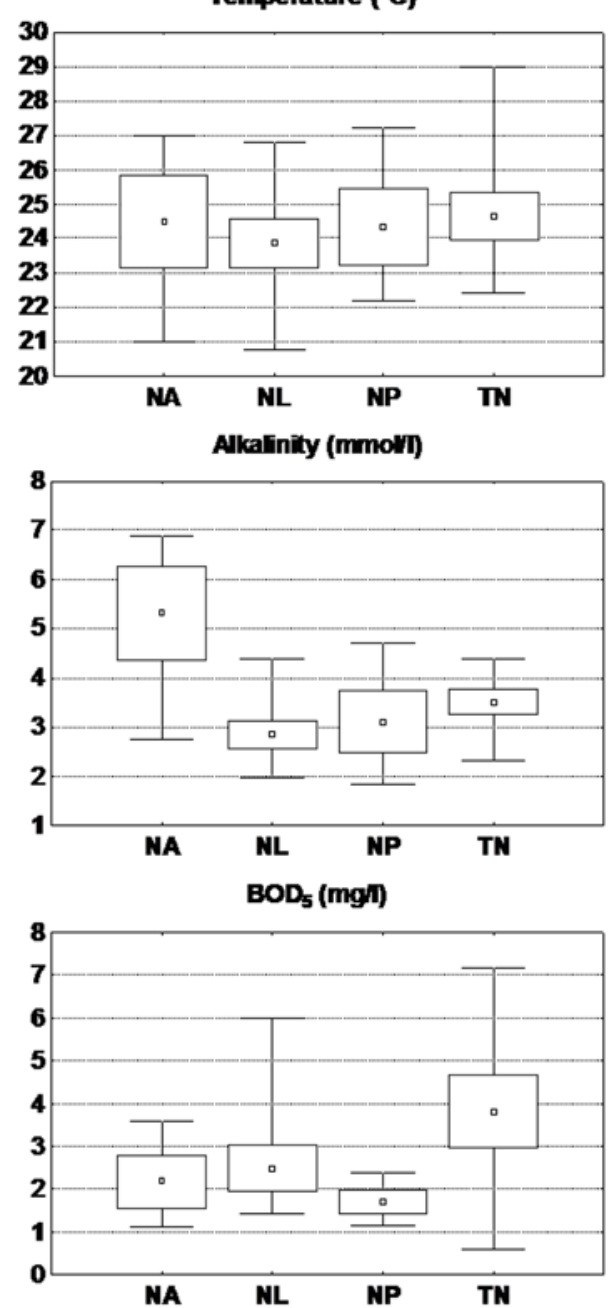

$\mathrm{NO}_{3}{ }^{-}(\mathrm{mg} /)$
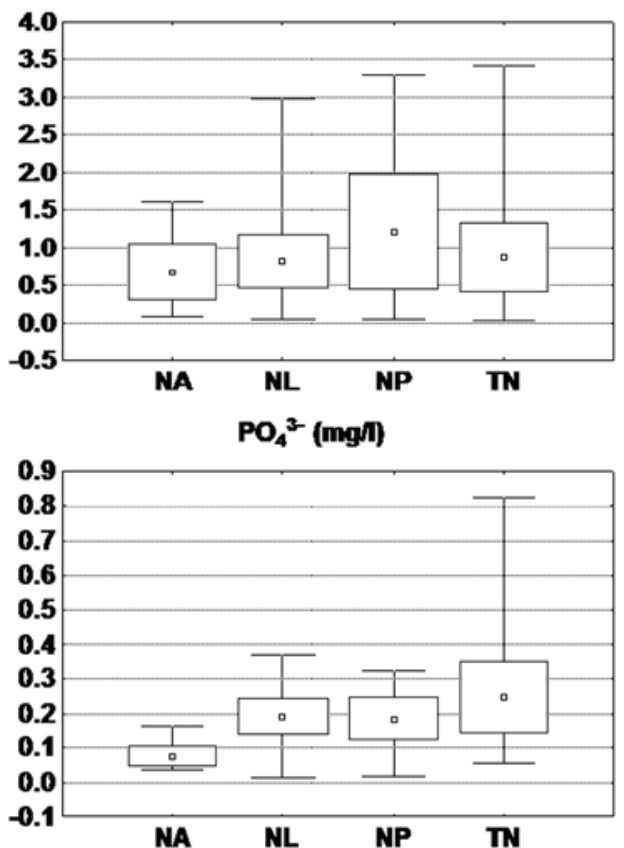

pH
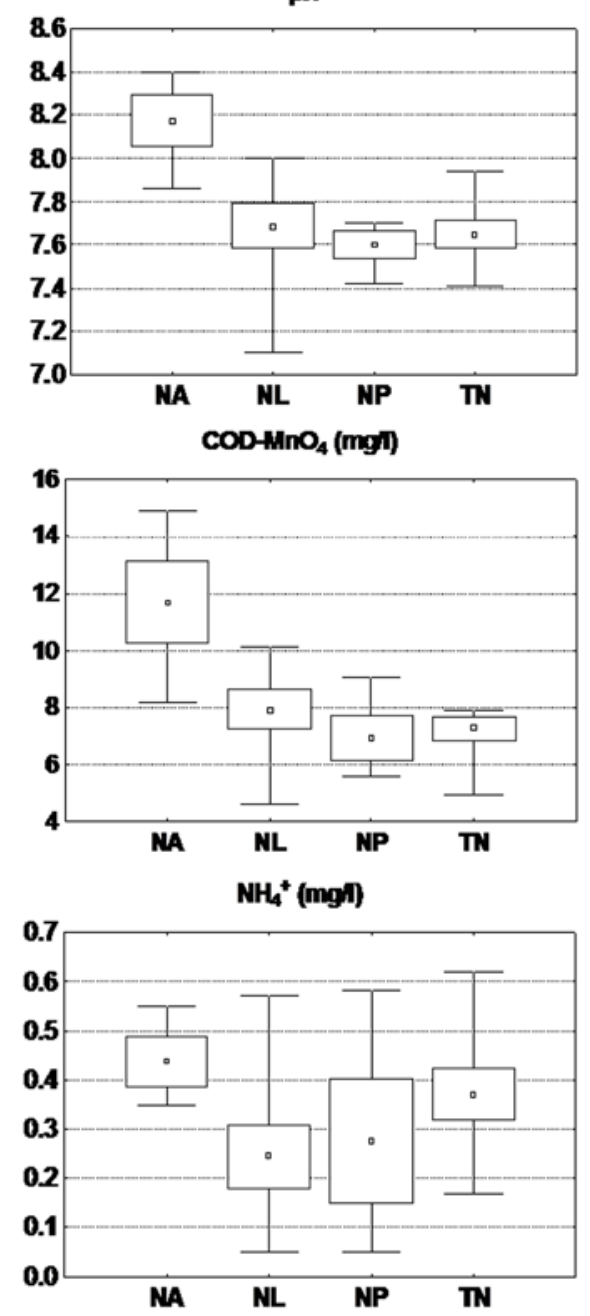

$\mathrm{NO}_{2}{ }^{-}(\mathrm{mg} / \mathrm{d})$
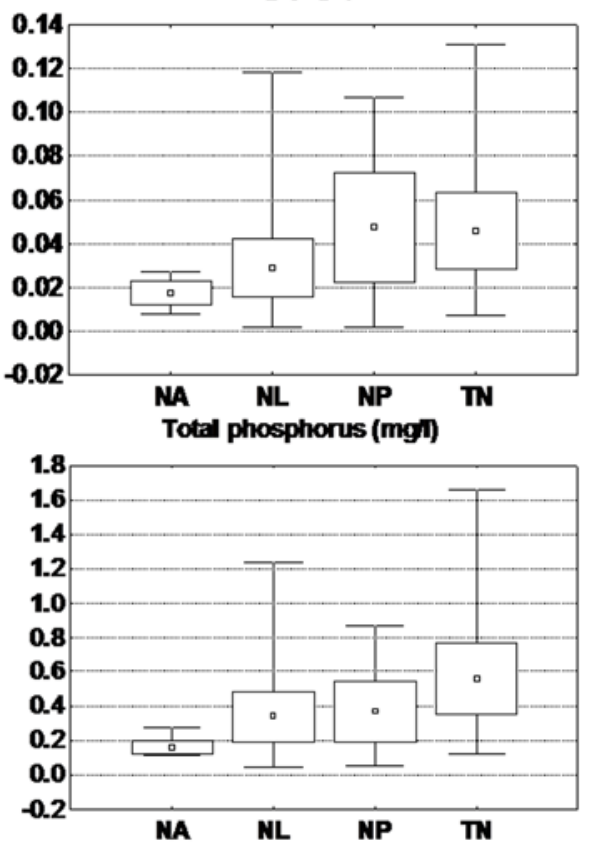

NA - Nymphaeetum albae NL - Nymphaeetum albo-luteae NP - Nymphoidetum peltatae TN - Trapetum natantis

$\square$ Mean MeantsE I Min-Max

Fig. 2 The main physical-chemical water parameters of the Nymphaeion alliance phytocenoses habitat. 
Tab. 2 Significance of differences between studied phytocoenoses compared to the analyzed water properties (ANOVA).

\begin{tabular}{|c|c|c|c|c|c|c|c|c|}
\hline Variable & $S S$ effect & $d f$ effect & $M S$ effect & SS error & $d f$ error & $M S$ error & F-ratio & $P$-value \\
\hline Temperature & 2.677 & 3 & 0.892 & 93.169 & 20 & 4.658 & 0.191 & 0.901 \\
\hline $\mathrm{pH}$ & 0.916 & 3 & 0.305 & 1.067 & 20 & 0.053 & 5.725 & $0.005^{\star *}$ \\
\hline Alkalinity & 17.134 & 3 & 5.711 & 23.439 & 20 & 1.172 & 4.873 & $0.010^{*}$ \\
\hline $\mathrm{COD}-\mathrm{MnO}_{4}$ & 62.933 & 3 & 20.978 & 68.225 & 20 & 3.411 & 6.149 & $0.004^{\star \star}$ \\
\hline $\mathrm{BOD}_{5}$ & 15.172 & 3 & 5.057 & 61.969 & 20 & 3.098 & 1.632 & 0.214 \\
\hline $\mathrm{NH}_{4}^{+}$ & 0.129 & 3 & 0.043 & 0.608 & 20 & 0.030 & 1.414 & 0.268 \\
\hline $\mathrm{NO}_{3}^{-}$ & 0.638 & 3 & 0.212 & 27.512 & 20 & 1.375 & 0.154 & 0.925 \\
\hline $\mathrm{NO}_{2}^{-}$ & 0.003 & 3 & 0.001 & 0.035 & 20 & 0.002 & 0.585 & 0.632 \\
\hline $\mathrm{PO}_{4}^{3-}$ & 0.078 & 3 & 0.026 & 0.808 & 20 & 0.040 & 0.641 & 0.597 \\
\hline Total phosphorus & 0.445 & 3 & 0.148 & 3.999 & 20 & 0.200 & 0.743 & 0.539 \\
\hline
\end{tabular}

$S S$ - sum of squares; $d f$ - degrees of freedom; $M S$ - mean squares. ${ }^{\star} P<0.05 ;{ }^{* *} P<0.01$.

alliance phytocenoses. Mean values ranged from 0.017 in Nymphaeetum albae stands to 0.047 in Nymphoidetum peltatae stands (Fig. 2).

The water-dissolved phosphorus content analysis revealed that the stands of ass. Trapetum natantis formed in water with a higher dissolved phosphorus content (mean value 0.246 ). The dissolved phosphorus mean content in water with ass. Nymphaeetum albo-luteae stands was 0.191, whereas 0.185 was measured for water with ass. Nymphoidetum peltatae (Fig. 2). Stands of ass. Nymphaeetum albae developed in water with a much lower dissolved phosphorus value in comparison to the other stands (mean value 0.08 ), where minimum variation in the measured values was also noted.

Although notable, the differences in the total phosphorus content for different localities are not statistically significant (Tab. 2). Stands of Trapetum natantis developed in water relatively richer in phosphates (mean value 0.556), compared to the other analyzed phytocenoses, in which a wide range of values was noted $(\min =0.123, \max =1.662)$. These are followed by habitats in which ass. Nymphoidetum peltatae (mean value 0.371), ass. Nymphaeetum albo-luteae (mean value 0.350 ) and ass. Nymphaeetum albae (mean value 0.164 ) develop.

Tab. 3 Significant of differences in water properties between studied phytocoenoses (Fisher LSD-test).

\begin{tabular}{|c|c|c|c|}
\hline Water properties & NA-NL & NA-NP & NA-TN \\
\hline $\mathrm{pH}$ & 0.002 & 0.002 & 0.001 \\
\hline Alkalinity (mmol/l) & 0.001 & 0.009 & 0.013 \\
\hline $\mathrm{COD}-\mathrm{MnO}_{4}(\mathrm{mg} / \mathrm{l})$ & 0.003 & 0.001 & 0.001 \\
\hline
\end{tabular}

NA - Nymphaeetum albae; NL - Nymphaeetum albo-luteae; NP Nymphoidetum peltatae; TN - Trapetum natantis. The differences between NL-NP, NL-TN and NP-TN are insignificant.

\section{Discussion}

Among the water properties analyzed as a part of this study, $\mathrm{pH}$, alkalinity and $\mathrm{COD}-\mathrm{MnO}_{4}$ are the most significant, and are the main contributors to the differentiation of phytocenoses Nymphaeetum albae, Nymphaeetum albo-luteae, Nymphoidetum peltatae and Trapetum natantis (Tab. 2, Fig. 3). Dawson and Szoszkiewicz [23] also reported that, in British rivers, $\mathrm{pH}$ and alkalinity, in addition to total phosphorus, are the key environmental parameters that significantly affect the differentiation of aquatic phytocenoses. In many European river systems, the role of alkalinity and $\mathrm{pH}$ is crucial in the differentiation and development of macrophytes, i.e., these parameters are directly correlated with the macrophyte distribution and abundance [42].

In the stands of Nymphaeetum albae, the highest mean $\mathrm{pH}$ value in relation to other Nympheion alliance phytocenoses, as well as the measured extreme values, are in accordance with the results reported by Szańkowski and Kłosowski [6] for aquatic ecosystems in Poland. However, all measured values are below the limits that define a "good ecological status" for artificial water bodies. High water alkalinity levels, as well as wide ecological amplitude for this parameter, were noted by Smits et al. [43] and Dimopoulos et al. [24] in the ass. Nymphaeetum albae stands. The highest average COD$\mathrm{MnO}_{4}$ value and ammonium ion content, relative to other phytocenoses, indicates that these stands are periodically exposed to water laden with organic matter (attributed to the close proximity of the food industry factories). The lowest nitrate, nitrite, dissolved and total phosphorus content compared to other analyzed stands characterizes the conditions in which these stands develop as mesotrophic [44], which is in accordance with the previously reported results [24,45,46]. Lukács et al. [45] found that this association prefers water with markedly poor organic matters, and the stands of this phytocenosis are vulnerable in waters rich in nutrients. Mesotrophic status is confirmed by the significant 


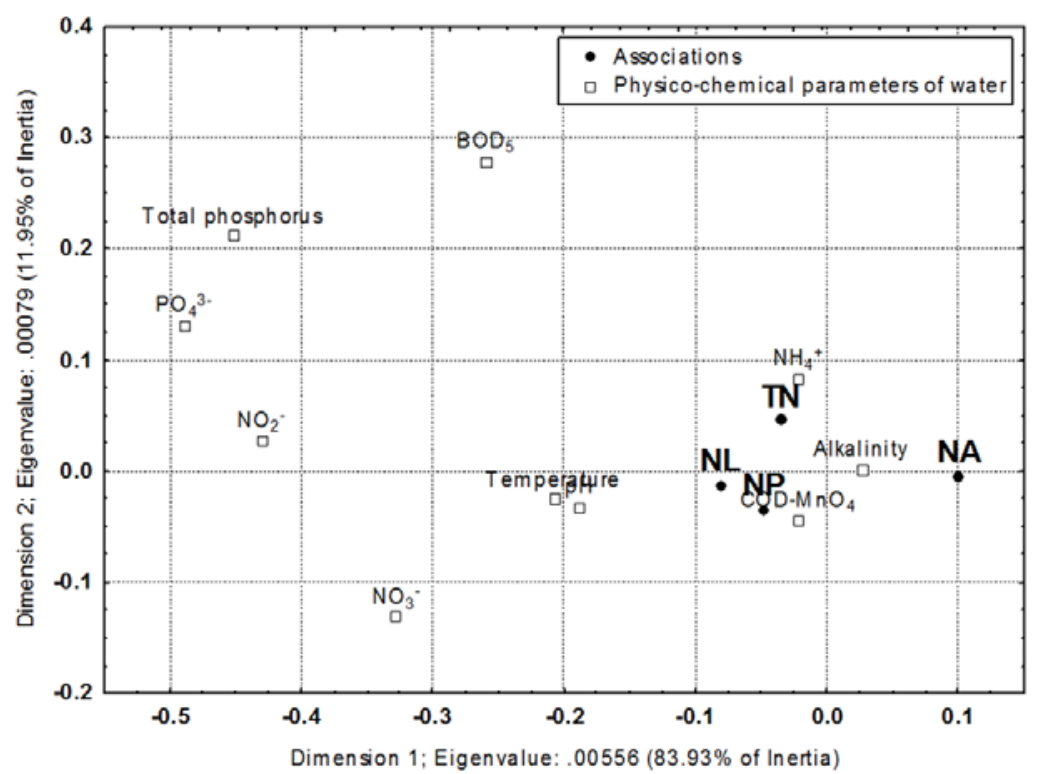

Fig. 3 Correspondence analysis between the identified Nymphaeion alliance associations and physical-chemical water quality parameters.

presence of M. spicatum in the stands of this community (Tab. 1). As M. spicatum growth decreases with further increases in the trophic level, it appears to act as its growth modulator $[47,48]$. This premise is supported by the highest abundance and coverage values for this macrophyte in the ass. Nymphaeetum albae stands, in relation to the other analyzed phytocenoses developing in waters characterized by higher trophic levels (Tab. 1, Fig. 2).

Our results, as well as the data reported in pertinent literature $[6,49]$, confirm that the habitat conditions in which ass. Nymphaeetum albo-luteae stands develop are subject to a wide range of variation. Slightly lower $\mathrm{pH}$ value and wide ecological valence of the Nuphar lutea edificator is confirmed by Kočić et al. [7] and Jabłońska and Kłosowski [8]. In the studied stands, the lowest alkalinity was noted, in comparison with the water in which stands of other phytocenoses develop. $\mathrm{BOD}_{5}$ value is in the range of "good ecological status" (below $6 \mathrm{mg} / \mathrm{l}$ ) [50]. Lower nitrate content in the water in which the stands of Nuphar lutea develop was also found in the rivers of neighboring Croatia [7]. The dissolved and total phosphorus values define these habitat conditions as moderately eutrophic [44], as confirmed by the data reported in pertinent literature $[9,11,51,52]$. Moreover, the species of the $C$. demersum characteristic group, which forms thick "underwater meadows" in the analyzed stands, is an indicator of eutrophic habitat conditions, in line with the results reported for other studies $[9,11,12,24,26,45,49,53,54]$.

In the stands of ass. Nymphoidetum peltatae, the lowest $\mathrm{pH}$ and the narrowest range of variation of this parameter were recorded. Szańkowski and Kłosowski [6] reported similar $\mathrm{pH}$ value for water flows in Poland. Bicarbonate values (min $=1.830, \max =4.734$ ) are in the range of variation noted by Smits et al. [43] most likely to allow development of edificator Nymphoides peltata. Significantly, the lowest COD- $\mathrm{MnO}_{4}$ and $\mathrm{BOD}_{5}$ values, as well as very narrow range of variation in these parameters, was noted in comparison to other analyzed phytocenoses. The highest nitrate and nitrite content in ass. Nymphoidetum peltatae habitats, in comparison to other analyzed phytocenoses, is in line with the findings reported by other authors $[6,46,53]$. The dissolved and total phosphorus values are in the range of eutrophic status, as indicated by the results of previous studies [6]. In addition to being an edificator, $H$. morsus-ranae, which was highly abundant in these stands, is also an indicator of eutrophic status [11,55]. On the other hand, according to Sýkora [51], development of this association is unaffected by water quality.

The most widespread floating-leaved vegetation in the canal network, ass. Trapetum natantis, is one of the most thermophilic aquatic phytocenoses $[21,56,57]$. The study findings indicate that the analyzed phytocenosis stands prefer neutral water, which is consistent with the results reported by other authors $[6,27]$. In contrast to the high COD- $\mathrm{MnO}_{4}$ values recorded by Szańkowski and Kłosowski [6], and low values determined by Kočić et al. [7], our results indicate that the habitats on which the analyzed stands form are moderately loaded with organic substances. Periodically measured, $\mathrm{BOD}_{5}$ values significantly higher than the "good ecological status" limit [50] are typically due to organic pollution caused by the discharge of untreated sewage, industrial effluents and leaching from agricultural land. These conditions are confirmed by the presence of Potamogeton pectinatus, which often develops in polluted waters, rich in phosphates $[7,9,23,58]$. Of particular significance is the ammonium ion content that, in certain localities, reaches $\max =0.62$, indicating that the water in which the stands developed is of impaired quality. Trapetum natantis stands developed in waters laden with phosphates, characterizing these conditions as eutrophic [44]. The highest dissolved and total phosphorus content, and very wide ecological amplitude of this important parameter, as an indicator of eutrophication, is characteristic of stands in other regions $[6,11,45]$. In addition to the edificator, hydrophytes $S$. polyrrhiza $[9,12,21,51,54,59], H$. morsus-ranae, C. demersum and L. minor $[21,51,59]$ are also well adapted to the eutrophic 
levels and are widely represented. Within Nymphaeion alliance phytocenoses, the mean value of phosphorus significantly exceeds the limit of "good ecological status" only in habitats of Trapetum natantis stands [50]. Moreover, the ability of $T$. natans to tolerate significant water level fluctuations in the studied hydromelioration facility, in conjunction with the physical-chemical water parameters, is driving its expansion [21].

Comparative analysis of the physical-chemical water parameters at the localities where the ass. Nymphaeion stands develop revealed that most phytocenoses are closely

\section{Acknowledgments}

This study was supported by the public water management company Vode Vojvodine, Novi Sad (Serbia). The authors would like to acknowledge two anonymous reviewers for constructive and helpful comments.

\section{Authors' contributions}

The following declarations about authors' contributions to the research have been made: wrote the paper: DD; field research: DD, BLM, LN; phytosociological analyses: DD; chemical analysis: DD, BLM, LN; preparation of distribution map: BLM; statistical analysis: BLM.

\section{References}

1. Kolada A. The use of aquatic vegetation in lake assessment: testing the sensitivity of macrophyte metrics to anthropogenic pressures and water quality. Hydrobiologia. 2010;656(1):133-147. http://dx.doi. org/10.1007/s10750-010-0428-Z

2. Soó R. A Magyar Flòra ès Vegetàciò Rendszertani-növènyföldrajzi Kèzikönyve I-VI. Budapest: Akadèmiai kiadò; 1964.

3. IUCN red list of threatened species [Internet]. 2013 [cited $2013 \mathrm{Nov}$ 29]; Available from: http://www.iucnredlist.org

4. Radulovic S, Boon PJ, Laketic D, Simonovic P, Puzovic S, Zivkovic $\mathrm{M}$, et al. Preliminary checklists for applying SERCON (system for evaluating rivers for conservation) to rivers in Serbia. Arch Biol Sci. 2012;64(3):1037-1056. http://dx.doi.org/10.2298/ABS1203037R

5. Butorac B. Review of aquatic vegetation of the regional park "Stari Begej”. Tiscia. 1995;29:27-32.

6. Szankowski M, Kłosowski S. Habitat conditions of nymphaeid associations in Poland. Hydrobiologia. 1999;415:177-185. http://dx.doi. org/10.1023/A:1003837520267

7. Kočić A, Hengl T, Horvatić J. Water nutrient concentrations in channels in relation to occurrence of aquatic plants: a case study in eastern Croatia. Hydrobiologia. 2008;603(1):253-266. http://dx.doi. org/10.1007/s10750-007-9276-X

8. Jabłońska E, Kłosowski S. Ecology of rare water plant communities in lakes of north-eastern Poland. Acta Soc Bot Pol. 2012;81(1):3-9. http://dx.doi.org/10.5586/asbp.2012.006

9. Balevičienè J, Balevičius A. Qualitative and quantitative parameters of phytocenoses in Lithuanian lakes of different trophic state. Ekologija. 2006;2:34-43. http://dx.doi.org/10.6001/ekologija.vi2.1077

10. Pełchaty M. Does nymphaeid distribution reflect the spatial heterogeneity of abiotic conditions in a shallow lake? Belg J Bot. 2007;140(1):73-82. http://dx.doi.org/10.2307/20794625

11. Schneider E. Aquatic macrophytes in the Danube Delta - indicators for water quality and habitat parameters. Stud Univ Babes Bolyai Biol. 2009;1:21-31.

12. Steffen K, Becker T, Herr W, Leuschner C. Diversity loss in the macrophyte vegetation of northwest German streams and rivers between the 1950s and 2010. Hydrobiologia. 2013;713(1):1-17. http://dx.doi. org/10.1007/s10750-013-1472-2

13. Bernez I, Daniel H, Haury J, Ferreira MT. Combined effects of environmental factors and regulation on macrophyte vegetation along three rivers in western France. River Res Appl. 2004;20(1):43-59. http://dx.doi.org/10.1002/rra.718 linked to specific habitat conditions. Water parameter values measured at most localities are the consequence of the anthropogenic eutrophication process. Owing to these adverse effects, it is likely that the biodiversity and survival of ass. Nympheion phytocenoses will be jeopardized [12]. Given that the phytocenoses that are endangered and vulnerable in most of the Europe have developed in this anthropogenic hydroecosystem, it is of paramount importance that its ecological equilibrium is maintained, in order to achieve "good ecological status" and preserve the stands of these immensely valuable phytocenoses.

14. O’Hare MT, Baattrup-Pedersen A, Nijboer R, Szoszkiewicz K, Ferreira T. Macrophyte communities of European streams with altered physical habitat. Hydrobiologia. 2006;566(1):197-210. http://dx.doi. org/10.1007/s10750-006-0095-2

15. Hrivnak R, Otahelova H, Valachovic M. The relationship between macrophyte vegetation and habitat factors along a middle-size European river. Pol J Ecol. 2007;55(4):717-729.

16. Breugnot E, Dutartre A, Laplace-Treyture C, Haury J. Local distribution of macrophytes and consequences for sampling methods in large rivers. Hydrobiologia. 2008;610(1):13-23. http://dx.doi.org/10.1007/ s10750-008-9418-9

17. Grinberga L. Environmental factors influencing the species diversity of macrophytes in middle-sized streams in Latvia. Hydrobiologia. 2010;656(1):233-241. http://dx.doi.org/10.1007/s10750-010-0432-3

18. Hrivnák R, Ot’ahel'ová $\mathrm{H}$, Valachovič $\mathrm{M}$, Pal'ove-Balang $\mathrm{P}, \mathrm{Ku}-$ binská A. Effect of environmental variables on the aquatic macrophyte composition pattern in streams: a case study from Slovakia. Fundam Appl Limnol. 2010;177(2):115-124. http://dx.doi. org/10.1127/1863-9135/2010/0177-0115

19. Radulovic S, Laketic D, Vukov D. A riverside tale: assessment of altered habitat effects on macrophyte assemblage on the river Tamiš, Serbia. Arch Biol Sci. 2010;62(4):1163-1174. http://dx.doi.org/10.2298/ ABS1004163R

20. Madsen JD, Chambers PA, James WF, Koch EW, Westlake DF. The interaction between water movement, sediment dynamics and submersed macrophytes. Hydrobiologia. 2001;444(1-3):71-84. http:// dx.doi.org/10.1023/A:1017520800568

21. Džigurski D, Ljevnaić-Mašić B, Nikolić L. Trapetum natantis Müller et Görs 1960 in hydromeliorative facilities in Serbia. Acta Soc Bot Pol. 2013;82(2):125-133. http://dx.doi.org/10.5586/asbp.2013.008

22. Džigurski D, Knežević A, Stojanović S, Nikolić L, Ljevnaić-Mašić B. The vegetation of canal Novi Sad-Savino Selo. Thaiszia. 2010;20:137-145.

23. Szoszkiewicz K, Dawson FH. Relationships of some ecological factors with the associations of vegetation in British rivers. In: Caffrey J, Barrett PRF, Ferreira MT, Moreira IS, Murphy KJ, Wade PM, editors. Biology, ecology and management of aquatic plants. Dordrecht: Springer Netherlands; 1999. p. 117-122. http://dx.doi. org/10.1007/978-94-017-0922-4

24. Dimopoulos P, Sykora KV, Gilissen C, Wiecherink D, Georgiadis T. Vegetation ecology of Kalodiki Fen (NW Greece). Biologia (Bratisl). 2005;60(1):69-82.

25. Paillisson JM, Marion L. Can small water level fluctuations affect the biomass of Nymphaea alba in large lakes? Aquat Bot. 2006;84(3):259266. http://dx.doi.org/10.1016/j.aquabot.2005.10.004

26. Nikolić L, Pajević S, Ljevnaić B. Primary production dynamics of dominant hydrophytes in Lake Provala (Serbia). Cent Eur J Biol. 2009;4(2):250-257. http://dx.doi.org/10.2478/s11535-009-0013-5

27. Hrivnák R. Aquatic plant communities in the catchment area of the Ipel' river in Slovakai and Hungary. Part II. Class Potametea. Thaiszia. 2002;12:137-160.

28. European Commission. Directive 2000/60/EC of the European Parliament and of the Council of 23rd October 2000: establishing a framework for Community action in the field of water policy. Off $\mathrm{J}$ Eur Communities. 2000;327:1-72. 
29. Hrivnák R, Otahel’ová H, Jarolímek I. Diversity of aquatic macrophytes in relation to environmental factors in the Slatina river (Slovakia). Biologia (Bratisl). 2006;61(4):413-419. http://dx.doi.org/10.2478/ s11756-006-0071-3

30. Ferreira MT, Aguiar FC. Riparian and aquatic vegetation in Mediterranean-type streams (western Iberia). Limnetica. 25(1-2):411-424.

31. Fabris M, Ghetti PF. Application and development of river quality bioindication methods based on macrophytes. In: 4th ECRR conference on river restoration Italy, Venice S. Servolo Island 16-21 June 2008. Venice: ECRR; 2008.

32. Milošev Ž. Hidrotehnički radovi u Banatu i Bačkoj pre izgradnje hidrosistema Dunav-Tisa-Dunav. Hidrosistem Dunav-Tisa-Dunav, 25 godina kasnije. Novi Sad: JVP Vode Vojvodine; 2002.

33. Braun-Blanquet J. Pflanzensoziologie. 3rd ed. Wien: Springer; 1964.

34. Josifović M, editor. Flora of SR Serbia. Beograd: SANU; 1970. (vol 1-9).

35. Tutin TG, Heywood VH, Burges NA, Valentine DH, Walters SM, Webb DA, editors. Flora Europaea. Cambridge: Cambridge University Press; 1964. (vol 1).

36. Tutin TG, Heywood VH, Burges NA, Moore DM, Valentine DH, Walters SM, et al., editors. Flora Europaea. Cambridge: Cambridge University Press; 1968. (vol 2-5).

37. Jávorka S, Csapody V. Icanographie der Flora des Südostlichen Mitteleuropa. Budapest: Akademiai Kiado; 1975.

38. APHA, AWWA, WPCF. Standard methods for examination of water and wastewater. 17th ed. Washington, DC: APHA; 1995.

39. STATISTICA 7.0. StatSoft; 2004.

40. Spałek K. Nymphaeetum albae Vollmar 1947 em. Oberd. in Oberd. et al. 1967, a plant association new to Poland. Acta Soc Bot Pol. 2007;76(1):81-84. http://dx.doi.org/10.5586/asbp.2007.011

41. Larson D. Growth of three submerged plants below different densities of Nymphoides peltata (S.G. Gmel.) Kuntze. Aquat Bot. 2007;86(3):280284. http://dx.doi.org/10.1016/j.aquabot.2006.10.007

42. Lewin I, Szoszkiewicz K. Drivers of macrophyte development in rivers in an agricultural area: indicative species reactions. Cent Eur J Biol. 2012;7(4):731-740. http://dx.doi.org/10.2478/s11535-012-0053-0

43. Smits AJM, de Lyon MJH, van der Velde G, Steentjes PLM, Roelofs JGM. Distribution of three nymphaeid macrophytes [Nymphaea alba L., Nuphar lutea (L.) Sm. and Nymphoides peltata (Gmel.) O. Kuntze] in relation to alkalinity and uptake of inorganic carbon. Aquat Bot. 1988;32(1-2):45-62. http://dx.doi.org/10.1016/0304-3770(88)90087-3

44. OECD. Eutrophication of waters: monitoring, assessment and control. Paris: Organisation for Economic Co-operation and Development; 1982.

45. Lukács BA, Dévai G, Tóthmérész B. Aquatic macrophytes as bioindicators of water chemistry in nutrient rich backwaters along the Upper-Tisza river (in Hungary). Phytocoenologia. 2009;39(3):287-293. http://dx.doi.org/10.1127/0340-269X/2009/0039-0287
46. Papastergiadou E, Babalonas D. The relationships between hydrochemical environmental factors and the aquatic macrophytic vegetation in stagnant and slow flowing waters. I. Water quality and distribution of aquatic associations. Arch Für Hydrobiol Suppl. 1993;90(4): 475-491.

47. Smith DH, Madsen JD, Dickson KL, Beitinger TL. Nutrient effects on autofragmentation of Myriophyllum spicatum. Aquat Bot. 2002;74(1):1-17. http://dx.doi.org/10.1016/S0304-3770(02)00023-2

48. Chase JM, Knight TM. Effects of eutrophication and snails on Eurasian watermilfoil (Myriophyllum spicatum) invasion. Biol Invasions. 2006;8(8):1643-1649. http://dx.doi.org/10.1007/s10530-005-3933-7

49. Lacoul P, Freedman B. Environmental influences on aquatic plants in freshwater ecosystems. Env Rev. 2006;14(2):89-136. http://dx.doi. org/10.1139/a06-001

50. Uredba o graničnim vrednostima zagadujućih materija u površinskim i podzemnim vodama i sedimentu i rokovima za njihovo dostizanje. Sl Glas RS. 2012;(50).

51. Sýkora KV. Field guide Dutch plant communities. Species composition and ecology. 2006.

52. Szoszkiewicz K, Kayzer D, Staniszewski R, Dawson H. Measures of central tendency of aquatic habitat parameters: application to river macrophyte communities. Pol J Ecol. 2010;58(4):693-706.

53. Nikolić L, Čobanović K, Lazić D. Nymphoides peltata (Gmel.) Kuntze, Myriophyllum spicatum L. and Ceratophyllum demersum L. biomass dynamics in Lake Provala (the Vojvodina Province, Serbia). Cent Eur J Biol. 2007;2(1):156-168. http://dx.doi.org/10.2478/s11535-007-0003-4

54. Grīnberga L, Springe G. Potential impact of climate change on aquatic vegetation of River Salaca, Latvia. Proc Latv Acad Sci Sect B Nat Exact Appl Sci. 2008;62(1-2):34-39. http://dx.doi.org/10.2478/ v10046-008-0011-4

55. Staniszewski R. Estimation of river trophy in the Kujawskie Lakeland using mean trophic rank and chemical index of trophy. Rocz AR Pozn Bot. 2001;4:165-173.

56. Coldea G, Sanda V, Popescu A, Ştefan N, editors. Les associations végétales de Roumanie. Cluj: Presses Universitaires de Cluj; 1997. (vol 1).

57. Olszewski T, Markowski T. Trapa natans L. s.l. as extinct in the 19th century component of Gdańsk Pomerania flora. In: Olszewski T, Afranowicz R, Bociąg K, editors. Contemporary trends of botanical research - on Professor Hanna Piotrowska 80th birthday anniversary. 2007. p. 153-156. (Acta Bot Cassub; vol 6).

58. Janauer G, Dokulil M. Macrophytes and algae in running waters. In: Ziglio G, Siligardi M, Flaim G, editors. Water quality measurements. Chichester: John Wiley \& Sons; 2006. p. 89-109. http://dx.doi. org/10.1002/0470863781.ch6

59. Kufel L, Strzałek M, Wysokińska U, Biardzka E, Oknińska S, Ryś K. Growth rate of duckweeds (Lemnaceae) in relation to the internal and ambient nutrient concentrations - testing the Droop and Monod models. Pol J Ecol. 2012;60(2):241-249. 